\title{
Nikolai Markov architecture. Architecture of changing times in Iran. Did Publications, 2004, (23 p. en anglais et $165 \mathrm{p}$. en persan).
}

\section{Marine Fromanger}

\section{(2) OpenEdition}

Journals

Édition électronique

URL : http://journals.openedition.org/abstractairanica/6119

DOI : 10.4000/abstractairanica.6119

ISSN : 1961-960X

Éditeur :

CNRS (UMR 7528 Mondes iraniens et indiens), Éditions de l'IFRI

Édition imprimée

Date de publication : 15 mai 2006

ISSN : 0240-8910

Référence électronique

Marine Fromanger, « Nikolai Markov architecture. Architecture of changing times in Iran. Did

Publications, 2004, (23 p. en anglais et 165 p. en persan). », Abstracta Iranica [En ligne], Volume 27 |

2006, document 240, mis en ligne le 02 janvier 2007, consulté le 25 septembre 2020. URL : http://

journals.openedition.org/abstractairanica/6119; DOI : https://doi.org/10.4000/abstractairanica.6119

Ce document a été généré automatiquement le 25 septembre 2020.

Tous droits réservés 


\title{
Nikolai Markov architecture.
} Architecture of changing times in Iran. Did Publications, 2004, (23 p. en anglais et $165 \mathrm{p}$. en persan).

\author{
Marine Fromanger
}

Cet ouvrage présente l'œuvre architecturale produite en Iran, entre 1925 et 1945, par Nikolai Markov (1882-1957). Né à Tiflis, il fut une figure avant-gardiste de son temps. Il réalisa une vingtaine de monuments, à Téhéran et en province, dans un style séduisant, mêlant une composition générale classique assez épurée, proche de l'art occidental, avec un décor et des motifs inspirés des décorations sassanides ou safavides. Ce mélange créa un style particulier, propre à l'Iran et de ce point de vue très intéressant. C'est aussi le reflet d'une société en mutation, qui se modernise tout en affirmant son identité nationale. L'ouvrage, très bien documenté, comporte une chronologie des œuvres de Markov, des photographies et des plans illustrant chaque monographie de monument. Cette publication est la première d'une série ambitieuse entreprise par les auteurs, consistant à analyser l'architecture iranienne de 1880 à nos jours, en commençant par des ouvrages consacrés aux travaux individuels d'architectes de cette période. Le projet est d'autant plus séduisant qu'il s'agit, comme c'est le cas ici, d'architecture de la période pahlavi, jusqu'ici peu étudiée. La partie rédigée en anglais manque cependant de précisions et de références permettant d'étayer certaines des affirmations avancées par les auteurs. 
INDEX

Thèmes : 5.1. Monde iranophone

\section{AUTEURS}

MARINE FROMANGER

Paris 